\title{
Somatic embryogenesis of hypocotyl derived calli from an eggplant cultivar
}

\author{
Hajar SABET ${ }^{1}$, Mahmood MALEKI ${ }^{2,3}$, Maryam ABDOLI NASAB ${ }^{2}$, Saeid MIRZAEI ${ }^{2}$
}

Somatic embryogenesis of hypocotyl derived calli from an eggplant cultivar

Abstract: Optimization of tissue culture and regeneration conditions of eggplant is necessary for achieving different goals such as gene transformation and the development of somaclonal variations. In this study, hypocotyl explants ware used to produce callus in a medium containing different concentrations of NAA and BAP. Moreover, the concentration of the elements $\mathrm{Ca}, \mathrm{Mn}, \mathrm{Mg}, \mathrm{Fe}$ and $\mathrm{K}$ were measured and analysed between embryogenic and non-embryogenic calli. For shoot elongation, embryogenic calli were transferred to a new culture medium containing 3.5 , 4 and $4.5 \mathrm{mg} \mathrm{l}^{-1}$ BAP plus $2 \mathrm{mg} \mathrm{l}^{-1} \mathrm{GA} 3$. Finally, produced shoots were rooted in a culture medium containing 1, 1.5 and $2 \mathrm{mg} \mathrm{l}^{-1}$ NAA. Results showed that the best treatment for the embryogenic callus induction was MS medium containing $0.5 \mathrm{mg} \mathrm{l}^{-1} \mathrm{BAP}$ plus $0.25 \mathrm{mg} \mathrm{l}^{-1} \mathrm{NAA}$. Two elements, Fe and $\mathrm{K}$, had the highest amount in non-embryogenic calli compare to the embryogenic one. For plant regeneration, MS medium containing $4.5 \mathrm{mg} \mathrm{l}^{-1} \mathrm{BAP}$ plus $2 \mathrm{mg} \mathrm{l}^{-1} \mathrm{GA} 3$ and $2 \mathrm{mg} \mathrm{l}^{-1} \mathrm{NAA}$ were the best treatments for shooting and rooting, respectively. In this study, the best treatments for plant regeneration produced 35 shoots from an explant with $92 \%$ shooting. This regeneration protocol could be useful for gene transformation and micro-propagation studies.

Key words: eggplant; tissue culture; somatic embryogenic regeneration; BAP; NAA

Abbreviations:

NAA Naphthaleneacetic acid

BAP 6-Benzylaminopurine

GA3 Gibberellic acid

MS medium Murashige \& Skoog Medium

IBA Indole-3-butyric acid

IAA Indole acetic acid
Received September 27, 2019; accepted January 20, 2020. Delo je prispelo 27. septembra 2019, sprejeto 20. januarja 2020.
Somatska embriogeneza hipokotilnih kalusov izbrane sorte jajčevca

Izvleček: Optimizacija tkivnih kultur jajčevca in regeneracijskih razmer sta potrebni za doseganje različnih ciljev kot sta genska transformacija in razvoj somaklonalne variabilnosti. $\mathrm{V}$ tej raziskavi so bili uporabljeni hipokotilni izsečki za pridobitev kalusa v gojiščih, ki so vsebovala različne koncentracije NAA in BAP. Med embriogenimi in neembriogenimi kalusi so bile izmerjene koncentracije elementov kot so $\mathrm{Ca}, \mathrm{Mn}, \mathrm{Mg}$, Fe in K. Za dolžinsko rast poganjkov so bili embriogeni kalusi premeščeni v drugo gojišče, ki je vsebovalo $3,5,4$ in $4,5 \mathrm{mg} \mathrm{l}^{-1}$ BAP in $2 \mathrm{mg} \mathrm{l}^{-1}$ GA3. Na koncu so bili poganjki ukoreninjeni v gojišču, ki je vsebovalo $1,1,5$ in $2 \mathrm{mg} \mathrm{l}^{-1}$ NAA. Rezultati so pokazali, da je bilo za indukcijo embriogenih kalusov najboljše MS gojišče, ki je vsebovalo $0,5 \mathrm{mg} \mathrm{l}^{-1} \mathrm{BAP}$ in $0,25 \mathrm{mg} \mathrm{l}^{-1} \mathrm{NAA}$. Dva elementa, Fe in $\mathrm{K}$, sta imela največjo vsebnost $\mathrm{v}$ ne-embriogenih kalusih $\mathrm{v}$ primerjavi $\mathrm{z}$ embriogenimi. Za regeneracijo rastlin, za nastanek in vkoreninjenje poganjkov, je bilo MS gojišče, ki je vsebovalo 4,5 $\mathrm{mg} \mathrm{l}^{-1} \mathrm{BAP}, 2 \mathrm{mg} \mathrm{l}^{-1} \mathrm{GA} 3$ in $2 \mathrm{mg} \mathrm{l}^{-1}$ NAA najboljše. V raziskavi je najboljše regeneracijsko obravnavanje dalo 35 poganjkov iz enega izsečka z 92 \% vkoreninjenjem. Ta regeneracijski protocol bi lahko bil koristen za gensko transformacijo in raziskave mikro propagacije.

Ključne besede: jajčevec; tkivna kultura; regeneracija $\mathrm{s}$ somatsko embriogenezo; BAP; NAA

Okrajšave:

NAA Naftalen ocetna kislina

BAP 6-Benzil aminopurin

GA3 Giberelinska kislina

MS gojišče Murashige \& Skoog gojišče

IBA Indol-3-maslena kislina

IAA Indol ocetna kislina

1 MSc student of Plant Breeding, Graduate University of Advanced Technology, Kerman, Iran

2 Department of Biotechnology, Institute of Science and High Technology and Environmental Sciences, Graduate University of Advanced Technology, Kerman, Iran

3 Corresponding author, e-mail: maleki.li@gmail.com 


\section{INTRODUCTION}

Eggplant (Solanum melongena L., $2 n=2 x=24$ ) is one of the important plants of the Solanaceae family (Portis, et al., 2018), which grown for its often purple edible fruit. Different cultivars of eggplant have different sizes, shapes and colours ranging from oval or egg-shaped to long club-shaped; and from white, yellow, green through degrees of purple pigmentation to almost black (Aminifard, et al., 2010). Eggplant after potatoes and tomatoes represents the third most important solanaceous crop species, and it is believed that eggplant is native to India and China (Magioli \& Mansour, 2005). Its bulk production is concentrated in China, India, Iran, Turkey, Egypt, Italy and Spain (Portis, et al., 2018).

Although the eggplant has a low calorie content, it is a rich source of magnesium, calcium, potassium and iron (Michalojc \& Buczkowska, 2008). In addition, in traditional medicine, eggplant is used to treat diabetes, arthritis, asthma and bronchitis (Magioli \& Mansour, 2005). Also, nasunin, as the major component of anthocyanin of eggplant, prevents lipid peroxidation (Igarashi, et al., 1993).

The tissue culture technique allows researchers to grow and manipulate plants under in-vitro sterile conditions and can be very useful to plant breeders (Bridgen et al., 2018). In fact, this technique can provide the diversities needed for selection the desired traits by inducing somaclonal variation. On the other hand, by optimizing the complete regeneration of callus, it is possible to transfer the desired genes to the desired plants (Chakravarthi, et al., 2010). Due to the reasons mentioned above, studies of the full plant regeneration from explants are of special importance in plants.

The fruit of the eggplant is found in the diet of many people in the world. For this reason, several studies have been carried out on regeneration of this plant through somatic embryogenesis using different explants such as leaf and cotyledon (Foo, et al., 2018), root (Franklin, et al., 2004) and hypocotyl (Statish, et al., 2015). However, it has been shown that plant regeneration can be affected by the cultivar. For example, Gandonou et al. (2005) showed that there is a significant difference between 9 genotypes of sugar beet in terms of callus induction capacity, embryogenic response and plant regeneration ability (Gandonou, et al., 2005), which indicates that the overall regeneration rate of the plant is genotype dependent. Hoque and Mansfield (2004), Schween and Schwenkel (2003) and Zale et al. (2004), working respectively on Oryza sativa L., Primula ssp. and wheat came to the same conclusions (Hoque \& Mansfield, 2004; Schween \& Schwenkel, 2003; Zale, et al., 2004). For this reason, in this study, regeneration of a native cultivar of Iran, Ghal- ami Varamin, which is commonly cultivated, was studied using somatic embryogenesis using hypocotyl explants.

\section{MATERIALS AND METHODS}

\subsection{SEED SURFACE STERILIZATION AND IN- VITRO GERMINATION}

This research was carried out on an Iranian eggplant variety called 'Ghalami Varamin'. Seeds of this variety were purchased from Pakan Bazr Esfahan Company (http://www.pakanbazr.com/en/). The seeds were surface-sterilized in $70 \%$ ethanol for 30 seconds and then $2 \%$ sodium hypochlorite for 10 minutes and rinsed 3 times with sterile distilled water. The MS medium was used for germination and seedlings growth of eggplant (Park \& Facchini, 2000). The MS medium (Duchefa Company) was prepared as $4.43 \mathrm{~g} \mathrm{l}^{-1}$. After adjusting to $\mathrm{pH} 5.7$ and adding agar $\left(7.5 \mathrm{~g}^{-1}\right)$ and sucrose $(3 \%)$, the culture medium was autoclaved. The MS medium was poured into autoclaved glass containers under sterile laminar hood. Seeds were cultured on the medium for germination, and placed in a growth chamber at $25 \pm$ $2{ }^{\circ} \mathrm{C}$ with a $16 / 8 \mathrm{~h}$ light/dark period, light intensity of $32.38 \mu \mathrm{mol} \mathrm{s}^{-1} \mathrm{~m}^{2-1}$.

\subsection{CALLUS INDUCTION CULTURE MEDIUM}

After 15 to 20 days, hypocotyl explants were placed in MS culture medium containing different concentrations of auxin (NAA) and cytokinin (BAP) to produce callus (Table 1). All treatments were carried out in 3 replicates. Then, the percentage of callus induction and embryogenic calluses, and fresh mass and dry mass of calluses were measured. All data were analysed by ANOVA as a factorial experiment based on a completely randomized design. BAP as first factor and NAA as second factor had seven and three levels, respectively. The mean comparisons were done based on the Duncan's Multiple Range Tests (Duncan, 1955).

\subsection{NUTRIENTS MEASUREMENT}

Embryogenic and non-embryogenic calli were washed in distilled water, oven dried at $70^{\circ} \mathrm{C}$ for $48 \mathrm{~h}$ and grounded after being weighed. Different ions concentration was taken from the chloride acid $(2 \mathrm{~N})$ extract of the samples that were measured using atomic absorption spectrometer (Varian Spectra aa220; made in Italy). All data were analysed by ANOVA based on a completely 
Table 1: Various hormonal treatments used to induce callus

\begin{tabular}{lll}
\hline Hormonal combination code & $\mathrm{BAP}\left(\mathrm{mg} \mathrm{l}^{-1}\right)$ & $\mathrm{NAA}\left(\mathrm{mg} \mathrm{l}^{-1}\right)$ \\
\hline A & 0 & 0 \\
B & 0 & 0.25 \\
C & 0 & 0.5 \\
D & 0.25 & 0 \\
E & 0.25 & 0.25 \\
F & 0.25 & 0.5 \\
G & 0.5 & 0 \\
H & 0.5 & 0.25 \\
I & 0.5 & 0.5 \\
J & 3.5 & 0 \\
K & 3.5 & 0.25 \\
L & 3.5 & 0.5 \\
M & 4 & 0 \\
N & 4 & 0.25 \\
O & 4 & 0.5 \\
P & 4.5 & 0 \\
Q & 4.5 & 0.25 \\
R & 4.5 & 0.5 \\
S & 5 & 0 \\
T & 5 & 0.25 \\
U & 5 & 0.5 \\
\hline
\end{tabular}

randomized design with three replications. The mean comparisons were done based on the Duncan's Multiple Range Tests.

\subsection{SHOOT PROLIFERATION MEDIUM}

The embryogenic calli isolated from the whole callus masses and transferred to the MS medium culture with different concentrations of BAP $(3.5,4$ and $4.5 \mathrm{mg}$ $\mathrm{I}^{-1}$ ) in order to shooting. Then, the percentage of shoot induction, shoot length, number of shoots and leaves were measured. In facts, the only treatments in this section were different concentrations of BAP that were analysed by ANOVA based on a completely randomized design with three replications. The mean comparisons were done based on the Duncan's Multiple Range Tests.

\subsection{ROOT PROLIFERATION MEDIUM}

For further prolongation and development of stem and leaf system, shoots were transferred to MS medium supplemented with $2 \mathrm{mg} \mathrm{l}^{-1}$ gibberellic acid (GA3). For root induction, shoot lengths of 3 to $4 \mathrm{~cm}$ were transferred to MS culture media containing different concentrations of NAA (1, 1.5 and $\left.2 \mathrm{mg} \mathrm{l}^{-1}\right)$. The studied traits included root induction percentage and root length. The only treatments in this section were different concentrations of NAA that were analysed by ANOVA based on a completely randomized design with three replications. The mean comparisons were done based on the Duncan's Multiple Range Tests.

\section{RESULTS AND DISCUSSIONS}

\subsection{CALLUS INDUCTION}

In this study, callus induction from hypocotyl explant was successfully performed. Callus initiation and appearance of embryogenic calli were occurred after 7 and 16 days, respectively (Figure 1 and 5). Embryogenic calli were seen in white, frangible and sponge-like forms so that after a while, the formations of shoot primordia in these calli were observed (Figure 1). But, non-embryogenic types appeared as compact, non-frangible, and sometimes greenish callus masses (Figure 1), similar to what was reported by other researchers (Corral-Martinez \& Segui-Simarro, 2012; Rivas-Sendra, et al., 2015). Eventually, these types of calli were necrosed and died on the medium.

The measured traits were the percentage of callus induction, percentage of embryogenic callus induction and fresh and dry mass of calluses. Variance analysis of data showed that there is a significant difference between different concentrations of BAP, NAA and their interactions at $1 \%$ probability level (Table 2 ).

The mean comparison of interaction effects of $\mathrm{NAA}^{\star} \mathrm{BAP}$ for induction of callus showed that the highest percentage of callus induction (85\%) observed in the MS media supplemented with the combination of 0.5 $\mathrm{mg} \mathrm{l^{-1 }} \mathrm{NAA}+4 \mathrm{mg} \mathrm{l}^{-1} \mathrm{BAP}$, and the lowest percentage of callus induction (zero) observed in combinations of $0 \mathrm{mg} \mathrm{l}^{-1} \mathrm{BAP}+0 \mathrm{mg} \mathrm{l}^{-1} \mathrm{NAA}, 4.5 \mathrm{mg} \mathrm{l}^{-1} \mathrm{BAP}+0 \mathrm{mg}$ $\mathrm{l}^{-1} \mathrm{NAA}$ and $5 \mathrm{mg} \mathrm{l}^{-1} \mathrm{BAP}+0.5 \mathrm{mg} \mathrm{l}^{-1} \mathrm{NAA}$ (Figure 2). Zayova et al., (2008) reported the highest induction of callus using hypocotyls $(63.3 \%)$ in the treatment MS media supplemented with $0.5 \mathrm{mg} \mathrm{l}^{-1} \mathrm{BAP}+2.0 \mathrm{mg} \mathrm{l}^{-1} \mathrm{NAA}$ (Zayova, et al., 2008). In another study, callus induction using cotyledons as explant, the highest callus induction $(100 \%)$ occurred in some concentrations of Kinetin, BAP and combinations of both (Foo, et al., 2018).

In this study, the highest percentage of embryogenic calli (52\%) was related to $0.5 \mathrm{mg} \mathrm{l}^{-1} \mathrm{BAP}+0.25 \mathrm{mg} \mathrm{l}^{-1}$ NAA. In the treatment with BAP alone, induction of cal- 

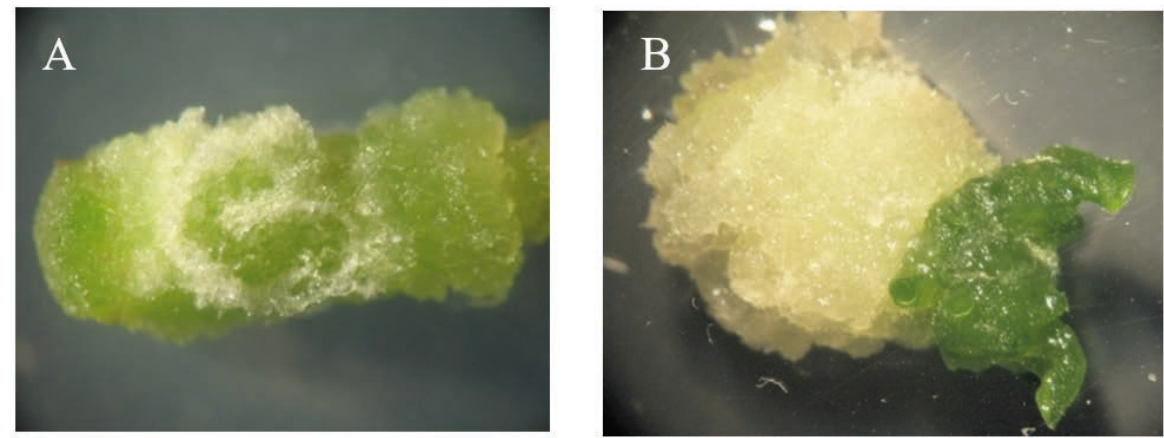

Figure 1: A: non-embryogenic callus. B: embryogenic callus

Table 2: Variance analysis of traits related to the callus induction section

\begin{tabular}{llllll}
\hline & & Mean Square & & \\
\cline { 3 - 5 } & & & & \\
Sources of variation & Degrees of freedom & Callusing percentage & $\begin{array}{l}\text { Percentage of embryo- } \\
\text { genic calluses }\end{array}$ & $\begin{array}{l}\text { Fresh mass } \\
(\mathrm{g})\end{array}$ & $\begin{array}{l}\text { Dry mass } \\
(\mathrm{g})\end{array}$ \\
\hline a (BAP) & 6 & & & $0.027^{* *}$ & $0.01^{* *}$ \\
b (NAA) & 2 & $0.35^{* *}$ & $0.11^{* *}$ & $0.029^{* *}$ & $0.017^{* *}$ \\
a b & 12 & $0.17^{* *}$ & $0.067^{* *}$ & $0.018^{* *}$ & $0.009^{* *}$ \\
error & 42 & $0.19^{* *}$ & $0.06^{* *}$ & 0.002 & 0.002 \\
\hline
\end{tabular}

** Significant differences between the treatments at the level of $1 \%$

lus in Ghalami Varamin cultivar occurred in all BAP concentrations except for the $4.5 \mathrm{mg} \mathrm{l}^{-1} \mathrm{BAP}$, and $0.5 \mathrm{mg} \mathrm{l}^{-1}$ was the best concentration (Figure 2). However, embryogenic calli occurred in $0.25,0.50,3.5$ and $4 \mathrm{mg} \mathrm{l}^{-1}$ treatments, and no embryogenic calli were recorded in the other two concentrations ( 4.5 and $5 \mathrm{mg} \mathrm{l}^{-1}$ ). In the study of Foo et al., (2018), the highest shoot formation from the cotyledon explants was induced on Kinetin $\left(2 \mathrm{mg} \mathrm{l}^{-1}\right)$ alone (Foo, et al., 2018). In our study, in addition to the best hormone composition selected, BAP alone induced embryogenic calli too while Foo et al. (2018), showed that kinetin alone is sufficient to induce shoots from the cotyledon explants (Foo, et al., 2018). It is likely, different concentrations of auxin and cytokinin hormones in the two tissues caused different results. Therefore, it seems that in the eggplant, depending on the type of explant, certain concentrations of auxin or cytokinin alone have the potential to induce embryogenic calli.

In our study, the NAA hormone (as a type of auxin) alone induced calli, but at a much lower rate than the BAP alone. In addition, the NAA hormone did not induce the embryogenic calli (Figure 2). Foo et al. (2018) revealed that all concentrations of another type of auxin, Kinetin, $\left(0.5,1,1.5\right.$ and $2 \mathrm{mg} \mathrm{l}^{-1}$ ) induced calli (Foo, et al., 2018). However, only two concentrations (1.5 and $2 \mathrm{mg} \mathrm{l}^{-1}$ ) induced embryogenic calli (Foo et al., 2018). Therefore, depending on the type of auxin, explant and the concentration used, this hormone alone can induce calli, especially embryogenic calli.

In the case of fresh and dry weight of callus, the concentrations of $5 \mathrm{mg} \mathrm{l}^{-1} \mathrm{BAP}+0.25 \mathrm{mg} \mathrm{l}^{-1} \mathrm{NAA}$ and $4.5 \mathrm{mg} \mathrm{l}^{-1} \mathrm{BAP}+0.25 \mathrm{mg} \mathrm{l}^{-1} \mathrm{NAA}$ showed the highest results respectively (Figure 3 ).

\subsection{COMPARISON OF IONS IN EMBRYOGENIC AND NON-EMBRYOGENIC CALLUS}

Concentration of five elements, calcium, magnesium, iron, potassium and manganese were measured in embryogenic and non-embryogenic calli. The results of variance analysis showed that there is no significant difference between the two embryogenic and non-embryogenic calli for calcium, magnesium, and manganese. But 


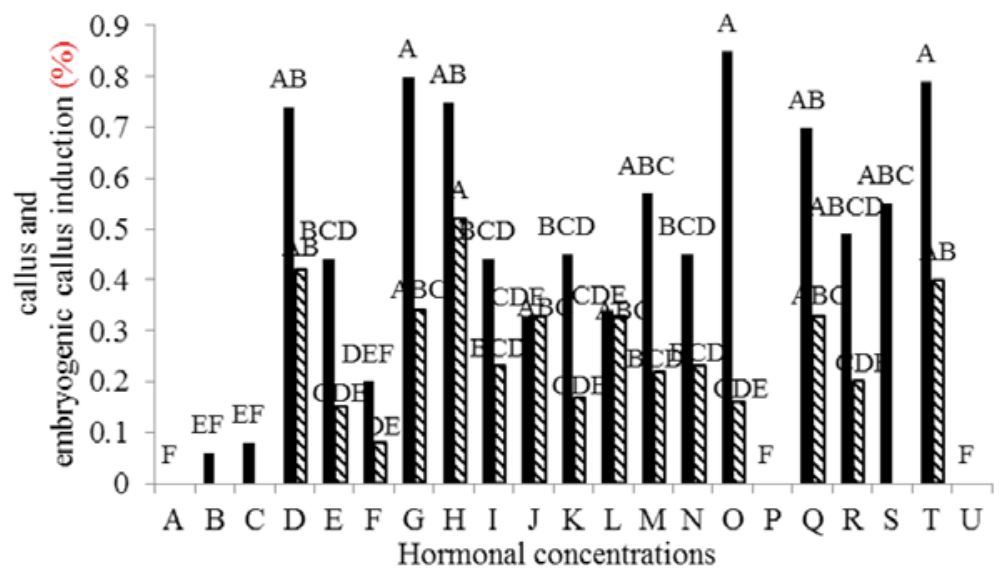

Figure 2: Mean comparison of the interaction effects of NAA*BAP for the percentage of callus induction and embryogenic callus induction. Black columns are percentage of callus induction and others are related to the percentage of embryogenic callus induction

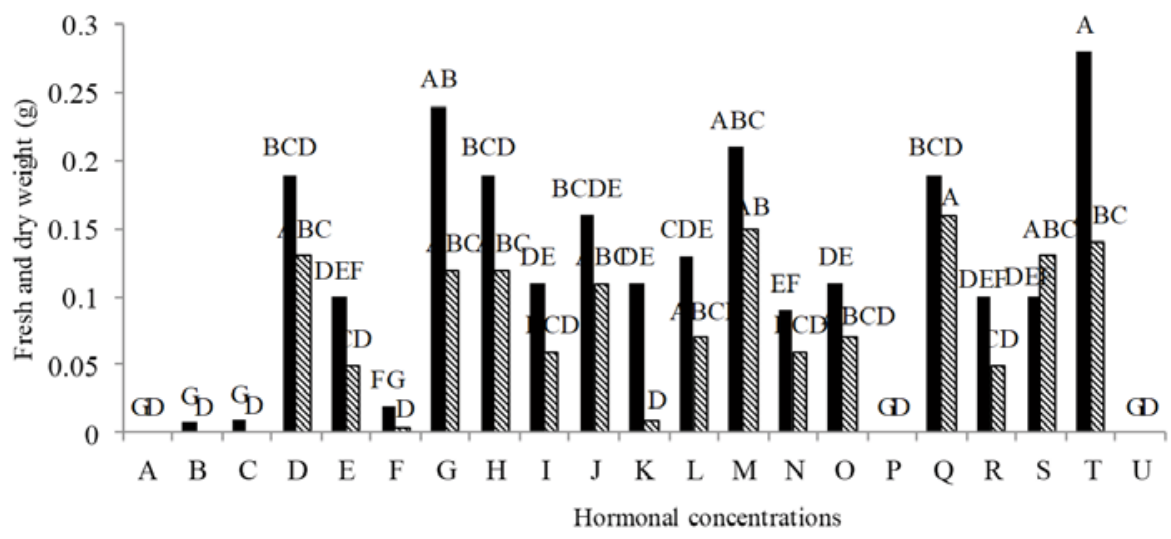

Figure 3: Mean comparison of the interaction effects of NAA BAP for fresh and dry mass of calli. Black columns are fresh mass of calli trait and others are related to the dry mass of calli

iron and potassium were dissimilar between embryogenic and non-embryogenic calli (Table 3). Our results revealed that the amount of both iron and potassium were more in non-embryogenic calli than the embryogenic ones (Fig. 4). Unfortunately, there is no report so far on the difference between the embryogenic and non-embryogenic calli in terms of the amount of these elements.

\subsection{PLANT REGENERATION}

\subsubsection{Shooting}

Shooting was initiated by transferring embryogenic calli to MS medium containing 3.5, 4 and $4.5 \mathrm{mg} \mathrm{l}^{-1}$ BAP. For shooting regeneration, some traits including shooting percentage, number of shoots, Shoots length and number of leaves were measured. Variance analysis for these traits showed that there are significant differences between them (Table 4).

The mean comparisons showed that the highest percentage of shooting (94\%), number of shoots (35 shoots), shoot length $(25 \mathrm{~cm})$ and leaf number (14 leaves) were observed with a MS medium containing $4.5 \mathrm{mg} \mathrm{l}^{-1} \mathrm{BAP}+2$ $\mathrm{mg} \mathrm{l}^{-1}$ GA3 (Table 5).

Different explants have been used for eggplant regeneration including hypocotyl (Mallaya \& Ravishankar, 2013), leaf (Ray et al., 2011) and cotyledon (Rahman et al., 2006; Shivaraj \& Rao, 2011), epicotyl and stem node, root (Ray et al., 2011). The highest percentages of shooting in various studies were different based on types of explant. Kaur et al. (2013) showed that cotyledon induced significantly the highest somatic embryogenesis on MS media fortified with $1.5 \mathrm{mg} \mathrm{l}^{-1} \mathrm{IBA}+1.0 \mathrm{mg} \mathrm{l}^{-1} \mathrm{BAP}$ (89.62\%). In 
Table 3: Variance analysis of iron and potassium amounts between embryogenic and non-embryogenic calli

\begin{tabular}{llll}
\hline & & Mean Square \\
\cline { 3 - 4 } & & & $\mathrm{K}$ \\
Sources of variation & Degrees of freedom & $\mathrm{K}$ & $0.133^{\star *}$ \\
treatment & 1 & $81.99^{\star *}$ & 0.002 \\
error & 1 & 1.47 & \\
\hline
\end{tabular}

** Significant differences at the level of $1 \%$

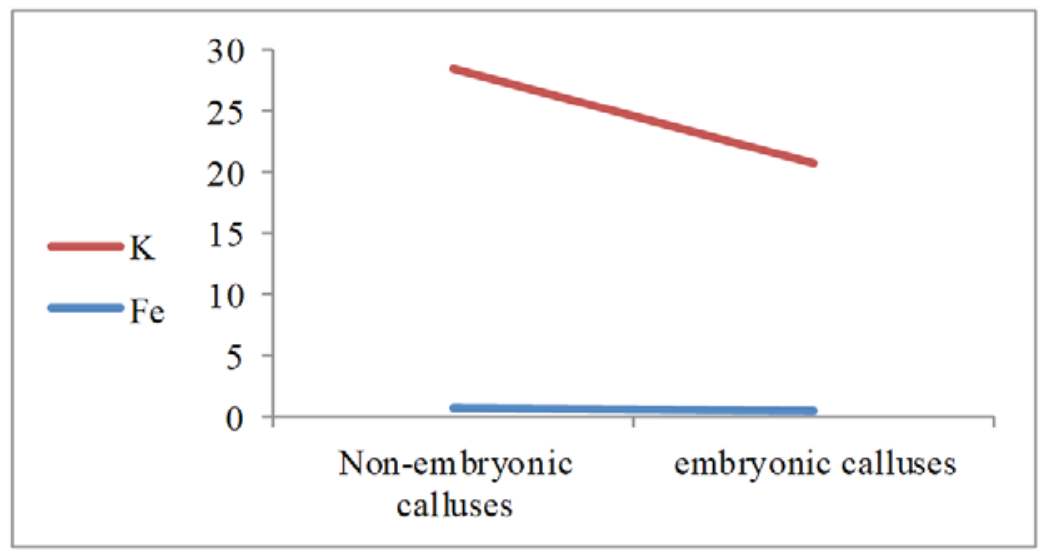

Figure 4: Mean comparison of iron and potassium amounts between embryogenic and non-embryogenic calli

Table 4: Analysis of variance of shooting traits

\begin{tabular}{llllll}
\hline \multicolumn{5}{c}{ Mean Square } \\
\cline { 3 - 6 } & & & & \\
\hline Sources of variation & Degrees of freedom & shooting percentage & number of shoots & Shoots length (cm) & number of leaves \\
treatment & 2 & $0.172^{* *}$ & $540.7^{* *}$ & $352.44^{* *}$ & $121.33^{* *}$ \\
error & 6 & 0.001 & 10.33 & 3.77 & 1.22 \\
\hline
\end{tabular}

** Significant differences at the level of $1 \%$

Table 5: Mean comparison of different concentrations of BAP on traits related to shoot elongation

\begin{tabular}{llllll}
\hline number of leaves & Shoots length $(\mathrm{cm})$ & number of shoots & shooting percentage & $\mathrm{GA}_{3}\left(\mathrm{mg} \mathrm{l}^{-1}\right)$ & $\mathrm{BAP}\left(\mathrm{mg} \mathrm{l}^{-1}\right)$ \\
\hline $2^{\mathrm{b}}$ & $5^{\mathrm{c}}$ & $9^{\mathrm{b}}$ & $0.47^{\mathrm{c}}$ & 2 & 3.5 \\
$3^{\mathrm{b}}$ & $9^{\mathrm{b}}$ & $15^{\mathrm{b}}$ & $0.62^{\mathrm{b}}$ & 2 & 4 \\
$14^{\mathrm{a}}$ & $25^{\mathrm{a}}$ & $35^{\mathrm{a}}$ & $0.94^{\mathrm{a}}$ & 2 & 4.5 \\
\hline
\end{tabular}

Table 6: Analysis of variance of rooting traits

\begin{tabular}{llll}
\hline & & Mean Square & \\
\cline { 3 - 4 } Sources of variation & Degrees of freedom & rooting percentage & root length $(\mathrm{cm})$ \\
\hline Treatment & 2 & $0.06^{* *}$ & $30.33^{* *}$ \\
Error & 6 & 0.001 & 1.22 \\
\hline
\end{tabular}

** Significant differences at the level of $1 \%$ 
Table 7: Mean comparison of different concentrations of NAA on traits related to root induction

\begin{tabular}{lll}
\hline $\mathrm{NAA}\left(\mathrm{mg} \mathrm{l}^{-1}\right)$ & rooting percentage & root length $(\mathrm{cm})$ \\
\hline 1 & $0.6^{\mathrm{b}}$ & $4.5^{\mathrm{b}}$ \\
1.5 & $0.71^{\mathrm{b}}$ & $5^{\mathrm{b}}$ \\
2 & $0.9^{\mathrm{a}}$ & $10^{\mathrm{a}}$ \\
\hline
\end{tabular}

leaf explant, it was also the maximum on $1.5 \mathrm{mg} \mathrm{l}^{-1} \mathrm{IBA}+$ $1.0 \mathrm{mg} \mathrm{l}^{-1} \mathrm{BAP}(69.60 \%)$. However, hypocotyl achieved the maximum of $38.41 \%$ somatic embryogenesis on $0.5 \mathrm{mg} \mathrm{l}^{-1}$ IBA + $1.0 \mathrm{mg} \mathrm{l}^{-1}$ BAP (Kaur, et al., 2013). Mir et al., (2011) studied plant regeneration from different cultivars of eggplants with different explants. Their results showed that shoot induction percentage were different among the cultivars. The highest shoot induction percentage using hypocotyl (88.31\%), cotyledon (90\%) and root (60\%) were observed from PBSR-11 cultivar on MS medium containing $2.5 \mathrm{mg} \mathrm{l}^{-1} \mathrm{IAA}+0.5 \mathrm{mg} \mathrm{l}^{-1}$ BAP (Mir et al., 2011).

The number of shoots and shoot length in the most studies were low. For example, Ray et al. (2011) used stem, root and leaf explants for eggplant regeneration. They observed that the highest number of shoot regenerated through callus from stem containing $2.0 \mathrm{mg} \mathrm{l}^{-1} \mathrm{BAP}$ and $0.5 \mathrm{mg} \mathrm{l}^{-1} \mathrm{NAA}$ was 3.4 (Ray, et al., 2011). Shivaraj and Rao (2011) used cotyledonary leaf as explants for eggplant regeneration. Their results showed the highest number of shoots was 23.3 at $2 \mathrm{mg} \mathrm{l}^{-1} \mathrm{BAP}+0.5 \mathrm{mg} \mathrm{l}^{-1}$ Kinetin $(\mathrm{Kn})$, and the highest shoot length was $11.2 \mathrm{~cm}$ at $2 \mathrm{mg} \mathrm{l}^{-1} \mathrm{BAP}$
$+1.5 \mathrm{mg} \mathrm{l}^{-1} \mathrm{Kn}$ from cultivar Pusa Purple long (Shivaraj \& Rao, 2011).

Mallaya \& Ravishankar (2013) showed that the maximum number of shoot buds elongated and shoot length using hypocotyl explant were 19 and $3.3 \mathrm{~cm}$ respectively on $0.5 \mathrm{mg} \mathrm{l}^{-1} \mathrm{TDZ}+0.1 \mathrm{mg} \mathrm{l}^{-1} \mathrm{GA} 3$ (Mallaya \& Ravishankar, 2013). By comparing the study of other researchers with this study, it can be concluded that the use of 4.5 $\mathrm{mg} \mathrm{l}^{-1} \mathrm{BAP}$ and $2 \mathrm{mg} \mathrm{l}^{-1} \mathrm{GA} 3$ can provide a better result.

\subsubsection{Rooting}

Variance analysis of data showed that there was a significant difference between treatments for rooting percentage and root length traits (table 6).

In this study, rooting percentage and root length were $92 \%$ and $10 \mathrm{~cm}$ respectively at $2 \mathrm{mg} \mathrm{l}^{-1} \mathrm{NAA}$ (table 7; Figure 5). For root regeneration, the results of Shivaraj and Rao (2011) showed that the highest frequency and number of roots were $100 \%$ and 89.3 respectively on $3 \mathrm{mg} \mathrm{l}^{-1}$ IBA (Shivaraj \& Rao, 2011). Mallaya, \& Ravishankar (2013) reported that the highest number of root and root length were 4 and $5.6 \mathrm{~cm}$ respectively on $1 \mathrm{mg} \mathrm{l}^{-1}$ IBA (Mallaya \& Ravishankar, 2013).

\section{CONCLUSION}

In this study, the best treatments for plant regenera-

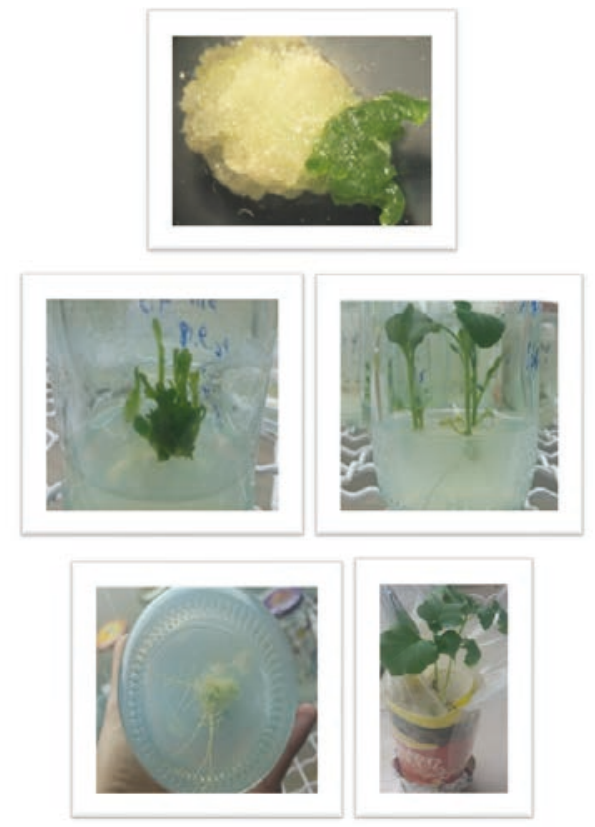

Figure 5: A: embryogenic callus. B: production of multiple shoots from embryogenic callus. C: production of roots in elongated shoots. D: production of roots. E: production of adult eggplant 
tion resulted in 35 shoots and $90 \%$ rooting from embryogenic calli. With our protocol, we could produce adult eggplant from embryogenic calli and then transferred to the pots (Figure 5). It seems that this protocol could be an efficient protocol for plant regeneration of eggplant specially Ghalami Varamin cultivar.

\section{ACKNOWLEDGEMENTS}

We are grateful to Institute of Science and High Technology and Environmental Sciences, Graduate University of Advanced Technology, Kerman, Iran.

\section{REFERENCES}

Aminifard, M. H., Aroiee, H., Fatemi, H., Ameri, A. \& Karimpour, S. (2010). Responses of eggplant (Solanum melongena L.) to different rates of nitrogen under field conditions. Journal of Central European Agriculture, 11(4), 453-458. https:// doi.org/10.5513/JCEA01/11.4.863

Bridgen, M. P., Van Houtven, W., \& Eeckhaut, T. (2018). Plant Tissue Culture Techniques for Breeding. Ornamental Crops. Springer, 127-144. https://doi.org/10.1007/978-3319-90698-0_6

Corral-Martínez, P., \& Seguí-Simarro, J. M. (2012). Efficient production of callus-derived doubled haploids through isolated microspore culture in eggplant (Solanum melongena L.). Euphytica, 187, 47-61. https://doi.org/10.1007/s10681012-0715-z

Chakravarthi, D., Rao, Y., Rao, M., \& Manga, V. (2010). Genetic analysis of in vitro callus and production of multiple shoots in eggplant. Plant Cell, Tissue and Organ Culture (PCTOC), 102, 87-97. https://doi.org/10.1007/s11240-010-9709-5

Duncan, D. B. (1955). Multiple range and multiple F tests. Biometrics, 11, 1-42. https://doi.org/10.2307/3001478

Foo, P. C., Lee, Z. H., Chin, C. K., Subramaniam, S., \& Chew, B. L. (2018). Shoot Induction in White Eggplant (Solanum melongena 'Bulat Putih') using 6-Benzylaminopurine and Kinetin. Tropical Life Sciences Research, 29, 119. https://doi. org/10.21315/tlsr2018.29.2.9

Franklin, G., Sheeba, C., \& Sita, G. L. (2004). Regeneration of eggplant (Solanum melongena L.) from root explants. In Vitro Cellular \& Developmental Biology-Plant, 40, 188-191. https://doi.org/10.1079/IVP2003491

Gandonou, C., Errabii, T., Abrini, J., Idaomar, M., Chibi, F., \& Senhaji, S. (2005). Effect of genotype on callus induction and plant regeneration from leaf explants of sugarcane (Saccharum sp.). African Journal of Biotechnology, 4.

Hoque, M. E., \& Mansfield, J. W. (2004). Effect of genotype and explant age on callus induction and subsequent plant regeneration from root-derived callus of Indica rice genotypes. Plant Cell, Tissue and Organ Culture, 78, 217-223. https://doi.org/10.1023/B:TICU.0000025640.75168.2d

Igarashi, K., Yoshida, T., \& Suzuki, E. (1993). Antioxidative activity of nasunin in chouja-nasu (little eggplant, Solanum melongena L'chouja'). Nippon Shokuhin Kogyo Gakkaishi, 40, 138-143. https://doi.org/10.3136/nskkk1962.40.138

Kaur, M., Dhatt, A. S., Sandhu, J. S., Sidhu, A. S., \& Gosal, S. S. (2013). Effect of media composition and explant type on the regeneration of eggplant (Solanum melongena L.). African Journal of Biotechnology, 12.

Magioli, C., \& Mansur, E. (2005). Eggplant (Solanum melongena L.): tissue culture, genetic transformation and use as an alternative model plant. Acta Botanica Brasilica, 19, 139148. https://doi.org/10.1590/S0102-33062005000100013

Mallaya, N. P., \& Ravishankar, G. (2013). In vitro propagation and genetic fidelity study of plant regenerated from inverted hypocotyl explants of eggplant (Solanum melongena 'Arka Shirish'. Biotech, 3, 45-52. https://doi.org/10.1007/ s13205-012-0068-2

Michalojc, Z., \& Buczkowska, H. (2008). Content of macroelements in eggplant fruits depending on nitrogen fertilization and plant training method. Journal of Elementology, 13.

Mir, K., Dhatt, A., Sandhu, J., \& Sidhu, A. (2011). Effect of genotype, explant and culture medium on organogenesis in brinjal. Indian Journal of Horticulture, 68, 332-335.

Park, S. U., \& Facchini, P. J. (2000). Agrobacterium rhizogenesmediated transformation of opium poppy, Papaver somniferum L., and California poppy, Eschscholzia californica Cham., root cultures. Journal of Experimental Botany, 51, 1005-1016. https://doi.org/10.1093/jexbot/51.347.1005

Portis, E., Lanteri, S., Barchi, L., Portis, F., Valente, L., Toppino, L., Rotino, G. L., et al. (2018). Comprehensive characterization of simple sequence repeats in eggplant (Solanum melongena L.) genome and construction of a web resource. Frontiers in Plant Science, 9, 401. https://doi.org/10.3389/ fpls.2018.00401

Rahman, M., Asaduzzaman, M., Nahar, N., \& Bari, M. (2006). Efficient plant regeneration from cotyledon and midrib derived callus in eggplant (Solanum melongena L.). Journal of Bio-Science, 14, 31-38. https://doi.org/10.3329/jbs. v14i0.439

Ray, B. P., Hassan, L., \& Sarker, S. K. (2011). In vitro cultivation and regeneration of Solanum melongena L. using stem, root and leaf explants. Nepal Journal of Biotechnology, 1, 49-54. https://doi.org/10.3126/njb.vli1.4172

Rivas-Sendra, A., Corral-Martínez, P., Camacho-Fernández, C., \& Seguí-Simarro, J. M. (2015). Improved regeneration of eggplant doubled haploids from microspore-derived calli through organogenesis. Plant Cell, Tissue and Organ Culture (PCTOC), 122, 759-765. https://doi.org/10.1007/ s11240-015-0791-6

Satish, L., Rameshkumar, R., Rathinapriya, P., Pandian, S., Rency, A. S., Sunitha, T., \& Ramesh, M. (2015). Effect of seaweed liquid extracts and plant growth regulators on in vitro mass propagation of brinjal (Solanum melongena L.) through hypocotyl and leaf disc explants. Journal of Applied Phycology, 27, 993-1002. https://doi.org/10.1007/s10811014-0375-6

Schween, G., \& Schwenkel, H. G. (2003). Effect of genotype on callus induction, shoot regeneration, and phenotypic stability of regenerated plants in the greenhouse of Primula ssp. Plant Cell, Tissue and Organ Culture, 72, 53-61. https://doi. org/10.1023/A:1021227414880 
Shivaraj, G., \& Rao, S. (2011). Rapid and efficient plant regeneration of eggplant (Solanum melongena L.) from cotyledonary leaf explants. Indian Journal of Biotechnology, 10, 125-129.

Zale, J. M., Borchardt-Wier, H., Kidwell, K. K., \& Steber, C. M. (2004). Callus induction and plant regeneration from mature embryos of a diverse set of wheat genotypes. Plant Cell, Tissue and Organ Culture, 76, 277-281. https://doi. org/10.1023/B:TICU.0000009248.32457.4c

Zayova, E., Nikova, V., Ilieva, K., \& Philipov, P. (2008). Callusogenesis of eggplant (Solanum melongena L.). Comptes Rendus De L Academie Bulgare Des Sciences, 61, 1485-1490. 